\title{
Angiotensin-II Is a Putative Neurotransmitter in Lactate- Induced Panic-Like Responses in Rats with Disruption of GABAergic Inhibition in the Dorsomedial Hypothalamus
}

\author{
Anantha Shekhar, ${ }^{1,2}$ Philip L. Johnson, ${ }^{1}$ Tammy J. Sajdyk, ${ }^{1}$ Stephanie D. Fitz, ${ }^{1}$ Stanley R. Keim, ${ }^{1}$ Pamela E. Kelley, ${ }^{1}$ \\ Donald R. Gehlert, ${ }^{3}$ and Joseph A. DiMicco ${ }^{2}$ \\ Departments of ${ }^{1}$ Psychiatry and ${ }^{2}$ Pharmacology and Toxicology, Institute of Psychiatric Research, Indiana University School of Medicine, Indianapolis, \\ Indiana 46202, and ${ }^{3}$ Neuroscience Division, Lilly Research Laboratories, Eli Lilly and Company, Indianapolis, Indiana 46285
}

\begin{abstract}
Intravenous sodium lactate infusions or the noradrenergic agent yohimbine reliably induce panic attacks in humans with panic disorder but not in healthy controls. However, the exact mechanism of lactate eliciting a panic attack is still unknown. In rats with chronic disruption of GABA-mediated inhibition in the dorsomedial hypothalamus (DMH), achieved by chronic microinfusion of the glutamic acid decarboxylase inhibitor L-allylglycine, sodium lactate infusions or yohimbine elicits panic-like responses (i.e., anxiety, tachycardia, hypertension, and tachypnea). In the present study, previous injections of the angiotensin-II (A-II) type 1 receptor antagonist losartan and the nonspecific A-II receptor antagonist saralasin into the DMH of "panic-prone" rats blocked the anxiety-like and physiological components of lactate-induced panic-like responses. In addition, direct injections of A-II into the DMH of these panic-prone rats also elicited panic-like responses that were blocked by pretreatment with saralasin. Microinjections of saralasin into the DMH did not block the panic-like responses elicited by intravenous infusions of the noradrenergic agent yohimbine or by direct injections of NMDA into the $\mathrm{DMH}$. The presence of the A-II type 1 receptors in the region of the DMH was demonstrated using immunohistochemistry. Thus, these results implicate A-II pathways and the A-II receptors in the hypothalamus as putative substrates for sodium lactate-induced panic-like responses in vulnerable subjects.
\end{abstract}

Key words: anxiety; circumventricular organs; GABA; medial preoptic nucleus; organum vasculosum lamina terminalis; saralasin; stress; subfornical organ; losartan; $\mathrm{AT}_{1}$ receptor

\section{Introduction}

Panic attacks are severe episodes of anxiety accompanied by multiple physiological symptoms. Recurrent panic attacks are the key symptoms of panic disorder and are common in posttraumatic stress disorder (PTSD) and some severe phobias. Intravenous infusions of sodium lactate elicits panic attacks in the majority of panic disorder patients (Gaffney et al., 1988; Liebowitz et al., 1984; Reiman et al., 1984; Strohle et al., 2003) and some PTSD subjects (Rainey et al., 1987; Jensen et al., 1998) but not other anxiety (Gorman et al., 1985; Liebowitz et al., 1985) or pure depressive (Cowley et al., 1987; McGrath et al., 1988) disorders. Other so called "panicogenic" substances, such as the noradrenergic agent yohimbine (Charney et al., 1987), the adenosine receptor antagonist caffeine (Charney et al., 1985), and $\mathrm{CO}_{2}$ (Gorman et al., 1994), also induce panic attacks in panic disorder

Received Feb. 22, 2006; revised July 15, 2006; accepted July 17, 2006

This study was supported by United States Public Health Service Grants R01 MH 52691 and R01 MH 65702 (A.S.) and R01 MH 65697 (J.A.D.). We are grateful to Merck \& Company for providing the losartan and Dr. Robert Speth for generously providing the angiotensin II type $1 \mathrm{~A}$ and $1 \mathrm{~B}$ receptor peptides, which were used to confirm the specificity of the $A T_{1}$ R antibody.

Correspondence should be addressed to Dr. Anantha Shekhar, Department of Psychiatry, Indiana University School of Medicine, 1111 West 10th Street, Suite 313, Indianapolis, IN 46202. E-mail: ashekhar@iupui.edu. DOI:10.1523/JNEUROSCI.2491-06.2006

Copyright $\odot 2006$ Society for Neuroscience $\quad$ 0270-6474/06/269205-11\$15.00/0 patients but not in healthy controls. Although the sensitivity to lactate infusions has been known for nearly four decades (Pitts and McClure, 1967) and is thought to be a biomarker for panic disorder (Cowley and Arana, 1990), the neurobiological basis of this response is still unknown.

Within the "panic circuit" (Gorman et al., 2000; Shekhar et al., 2002), the hypothalamus plays a key role in initiating panic-like responses (Sano et al., 1970; Abelson and Curtis, 1996; Schreiber et al., 1996; Javanmard et al., 1999; Lipp et al., 2005). The dorsomedial hypothalamus (DMH) plays an important role coordinating the neuroendocrine, autonomic, and behavioral responses to emotional stress (DiMicco et al., 2002; Chou et al., 2003). Activation of the DMH of rats elicits panic-like responses, characterized by increases in anxiety, heart rate (HR), blood pressure (BP), respiration rate (RR), and "flight" behaviors (Shekhar and DiMicco, 1987; Shekhar, 1993; DiMicco et al., 1996; Shekhar et al., 1996; Shekhar and Keim, 1997; Samuels et al., 2002). Intravenous sodium lactate infusions lead to increased anxiety-like behaviors and panic-like physiological responses after disruption of GABA synthesis in the DMH region of rats (Shekhar et al., 1996; Shekhar and Keim, 1997), thus providing an animal model for human panic disorder.

Osmosensitive circumventricular organs (CVOs) of the anteroventral third ventricular region (AV3V), such as the subfor- 
nical organ (SFO), appear critical for sodium lactate responses in panic-prone rats (Shekhar and Keim, 1997). The SFO contains angiotensin II (A-II) and also sends major projections to hypothalamus (Ter Horst and Luiten, 1986; Thompson and Swanson, 1998; Chen and Smith, 2003). Also, stress-induced cardioexcitatory response are attenuated after blockade of A-II type 1 receptors ( $\mathrm{AT}_{1} \mathrm{Rs}$ ) in the DMH in rabbits (De Matteo et al., 2006) and $\mathrm{AT}_{1} \mathrm{R}$ antagonists are anxiolytic (Saavedra et al., 2006), suggesting that A-II, and specifically $\mathrm{AT}_{1} \mathrm{R}$, in the $\mathrm{DMH}$ may be involved in panic-like responses. To test this hypothesis, we (1) microinjected a nonselective A-II receptor and a selective $\mathrm{AT}_{1} \mathrm{R}$ antagonist into the DMH region, predicting that they would block responses to intravenous infusions of lactate but not responses elicited by the noradrenergic panicogen yohimbine, and (2) microinjected A-II into the DMH, predicting that it would elicit panic-like response in these rats. We also used immunohistochemistry to determine whether $\mathrm{AT}_{1}$ Rs are present in the $\mathrm{DMH}$.

\section{Materials and Methods}

Animals

All experiments were conducted on male Sprague Dawley rats (300-350 g; Harlan Laboratories, Indianapolis, IN) housed in individual plastic cages in a temperature-controlled room $\left(22^{\circ} \mathrm{C}\right)$ kept on a $12 \mathrm{~h}$ light/dark cycle and given access to food and water ad libitum. All studies were conducted in accordance with the National Institutes of Health Guidelines for the Care and Use of Laboratory Animals (publication number 80-23, revised 1996) and the guidelines of the Indiana University/Purdue University at Indianapolis Institutional Animal Care and Use Committee.

\section{Surgical procedures}

Before surgeries, rats were anesthetized by placing them in a closed Plexiglas box that was connected to an isoFlurane system (MGX Research Machine; Vetamic, Rossville, IN) and then with a nose cone connected to the same system during the surgeries. In the studies involving injections of the nonselective A-II receptor antagonist saralasin into the $\mathrm{DMH}$, rats were then fitted with femoral arterial catheters for recording BP and HR and venous catheters for intravenous infusions using a procedure described previously (Shekhar, 1993). For the losartan experiment, rats were implanted with femoral venous catheters, but BP and HR were measured by directly implanting telemetric probes into the abdominal aorta, which contains a pressure transducer (catalog \#C50-PXT; Data Science International, Arden Hills, MN). After $3 \mathrm{~d}$ of recovery, baseline reactivity to intravenous sodium lactate infusions, anxiety levels using the social interaction (SI) were determined for each rat as described below. The animals were reanesthetized and implanted with Alzet $(\mathrm{Cu}-$ pertino, CA) minipumps into the DMH as described previously (Shekhar et al., 1996). Briefly, an L-shaped guide cannula with a side arm attached to a small tygon tube was used for pump implantations. The target stereotaxic coordinates for the DMH (anterior, $2.4 \mathrm{~mm}$; lateral, $1.0 \mathrm{~mm}$; and ventral, $8.5 \mathrm{~mm}$ from bregma) sites were obtained from a standard stereotaxic atlas (Paxinos and Watson, 1986), and the cannulas were implanted using a $10^{\circ}$ angle from the vertical plane with the incisor bar set at a $+5^{\circ}$ angle. Once the cannula was placed at the coordinates of the $\mathrm{DMH}, 20 \mathrm{pmol} / 100 \mathrm{nl}$ of the $\mathrm{GABA}_{\mathrm{A}}$ receptor antagonist bicuculline methiodide (BMI) was injected by inserting an injection cannula through the guide cannula to ascertain that the tip was placed at the reactive site (i.e., where BMI elicits $>50$ beats/min increases in heart rate) in the DMH. Once the reactive site was found, the injection cannula was removed, the top of the guide cannula was sealed with an obturator, and the side tubing was connected to the metal connector in the Alzet minipump (model 2002) that was previously filled with a solution containing L-allylglycine (L-AG) (catalog \#A7762; Sigma, St. Louis, MO), an inhibitor of the GABA synthetic enzyme glutamic acid decarboxylase (GAD). The concentration of solution was such that $3.5 \mathrm{nmol} \cdot 0.5$ $\mu \mathrm{l}^{-1} \cdot \mathrm{h}^{-1}$ of the drug was infused into the DMH. The pump was then sutured under the skin in the nape of the neck, and the connector and cannula were cemented to the skull as described previously (Shekhar et al., 1996). Among the rats so implanted $(n=22)$, a subgroup of rats ( $n=$ 6) had an additional chronic microinjection cannula stereotaxically implanted in the lateral hypothalamus (LH), which was considered regions immediately lateral to the fornix and mammillothalamic tracts at the level of the DMH (Fig. 1A).

Sodium lactate infusion procedure for eliciting panic-like responses The lactate infusion procedure has been described previously (Shekhar et al., 1996). Briefly, rats are given intravenous infusions of $0.9 \%$ saline and $0.5 \mathrm{M}$ sodium lactate $(10 \mathrm{ml} / \mathrm{kg}$ over $15 \mathrm{~min})$, an approach similar to lactate infusions used as a diagnostic procedure in subjects with panic disorder (Liebowitz et al., 1984), in random order with at least 30 min recovery time between infusions. The HR, mean arterial BP, RR, and anxiety responses to lactate reported are the differences between changes elicited by lactate and saline infusions. For the losartan experiment, BP and HR were measured directly by telemetric probes. Windows-based Data Science International Dataquest software was used to monitor and record BP and HR. For the saralasin experiments, the arterial line was attached to a pressure transducer, which was directly connected to a Beckman Instruments (Montreal, Quebec, Canada) R511 Dynograph to monitor BP, HR, and RR. For the duration of each experiment, BP, HR, and RR (when applicable) were recorded continuously in freely moving conscious rats. In the losartan experiment, the data are expressed as changes in HR and BP from the average of the baseline $(-5$ to $-1 \mathrm{~min}$ before lactate infusions) from each treatment group and also the change in peak changes in HR or BP after lactate infusions. In the saralasin experiments, the data are expressed as the change in peak changes in HR or BP after lactate infusions. The peak for BP and HR was defined as the highest value sustained for 2 min or longer.

\section{Social interaction test}

A modified version of the SI test (File, 1980) was used to measure anxietylike responses in all lactate infusion experiments but not the direct injections of A-II or NMDA and yohimbine challenges. After infusion of lactate, the experimental rat was placed in an open field $(0.9 \mathrm{~m}$ long $\times$ $0.9 \mathrm{~m}$ wide with walls $0.3 \mathrm{~m}$ high) with an untreated novel partner rat. A video camera was fixed above the box, and all behavioral tests were videotaped. During the $5 \mathrm{~min}$ test, the total amount of time the treated rat initiated interaction with the partner rat was recorded (sniffing, grooming, etc.) as described previously (Shekhar and Keim, 1997). Videotaped sessions were scored at a later time by two raters, and a decrease in total interaction time was taken as an increase in "anxiety-like" behavior.

\section{Immunohistochemistry for A-II type 1 receptors}

Three male Wistar rats (250-275 g; Harlan Laboratories) were group housed in conditions as described previously in Materials and Methods. Rats were anesthetized with halothane and then perfused transcardially with $250 \mathrm{ml}$ of $0.1 \mathrm{M}$ PBS, followed by $250 \mathrm{ml}$ of $0.1 \mathrm{M}$ sodium phosphate buffer (PB) containing 4\% paraformaldehyde and 3\% sucrose. Brains were removed and rinsed for $24 \mathrm{~h}$ in $0.1 \mathrm{M} \mathrm{PB}$ and then placed in cryoprotectant $(30 \%$ sucrose in $0.1 \mathrm{M} \mathrm{PB})$ for an additional $4-5 \mathrm{~d}$. Brains were frozen by placing them in a glass beaker containing liquid isopentane that was previously cooled on dry ice. Serial coronal sections $(30 \mu \mathrm{m})$ were cut using a freezing microtome and were immediately placed in cryoprotectant consisting of $27 \%$ ethylene glycol and $16 \%$ glycerol in $0.1 \mathrm{M} \mathrm{PB}$ to yield three alternative sets of sections. Sections were stored at $-20^{\circ} \mathrm{C}$ until immunohistochemical processing. All solutions had a $\mathrm{pH}$ of 7.4.

Sections were washed in $0.1 \mathrm{M}$ PBS for $30 \mathrm{~min}$ and then incubated in $1 \% \mathrm{H}_{2} \mathrm{O}_{2}$ in PBS for $20 \mathrm{~min}$. Sections were then washed $10 \mathrm{~min}$ in PBS and 20 min in PBS with $0.3 \%$ Triton X-100 (PBST). Sections were incubated overnight $(\sim 12-16 \mathrm{~h})$ in PBST at room temperature with an affinity-purified rabbit anti- $\mathrm{AT}_{1} \mathrm{R}$ polyclonal antibody (1:250-1:500 dilution; catalog \#AB-N27AP; Advanced Targeting Systems, San Diego, $\mathrm{CA})$. Advanced Targeting Systems report the following: the $\mathrm{AT}_{1} \mathrm{R}$ antisera were generated in rabbits by immunization with the peptide PSDNMSSSAKKPASC [amino acids 341-355 of A-II type 1A receptor $\left(\mathrm{AT}_{1 \mathrm{~A}} \mathrm{R}\right)$ ] or with SSSAKKSASFFEVE [amino acids 346-359 of A-II type $1 \mathrm{~B}$ receptor $\left.\left(\mathrm{AT}_{1 \mathrm{~B}} \mathrm{R}\right)\right]$ conjugated to keyhole limpet hemocyanin; the $\mathrm{AT}_{1} \mathrm{R}$ antisera were then affinity purified by passage through two affinity columns, one cross-linked to $\mathrm{AT}_{1 \mathrm{~A}} \mathrm{R}$ and the other with $\mathrm{AT}_{1 \mathrm{~B}} \mathrm{R}$, resulting 

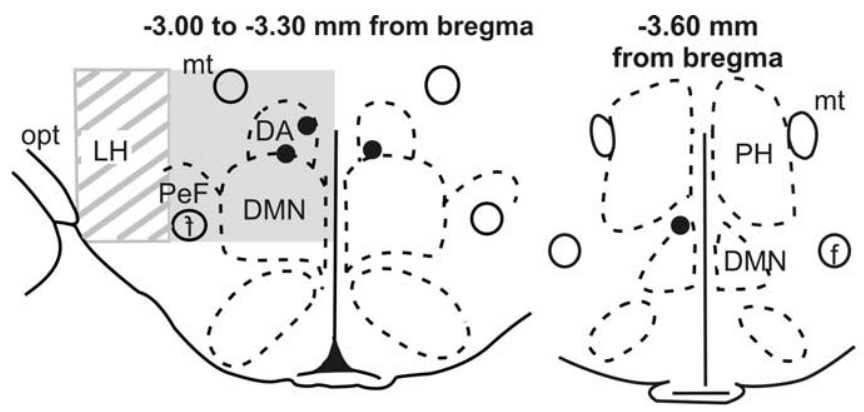

Figure 1. Illustration of osmotic minipump placements in the DMH/posterior hypothalamus from -3.30 to $-4.16 \mathrm{~mm}$ bregma for losartan and saralasin experiments. Black circles represent placements for losartan experiments. For saralasin experiments, gray shading represents distribution of minipumps residing in the DMH/posterior hypothalamus, whereas lateral hypothalamus (LH) placements were located in the immediately lateral to the DMH and are represented by the box filled with gray diagonal lines. DA, Dorsal hypothalamic area; f, fornix; mt, mammillothalamic tract; opt, optic tract; PH, posterior hypothalamus.

in specificity to the sequence PSDNMSSSAKKPASCFEVE (amino acids 341-359), and this $\mathrm{AT}_{1} \mathrm{R}$ antibody recognizes the $1 \mathrm{~A}$ and $1 \mathrm{~B}$ isoforms of the $\mathrm{AT}_{1} \mathrm{R}$ in the rat. The $\mathrm{AT}_{1} \mathrm{R}$ antibody was originally generated by $\mathrm{Dr}$. Robert Speth (The University of Mississippi School of Pharmacy, Oxford, MS) and has been characterized previously by preadsorbing it with the $\mathrm{AT}_{1 \mathrm{~A}} \mathrm{R}$ and $\mathrm{AT}_{1 \mathrm{~B}} \mathrm{R}$ peptides used to generate the $\mathrm{AT}_{1} \mathrm{R}$ antibody (Huang et al., 2003; Wang et al., 2004). We conducted additional characterization for the batch of $\mathrm{AT}_{1} \mathrm{R}$ antibody that was used in this study as noted below.

The following morning, the sections were washed in PBST for $30 \mathrm{~min}$ and then were incubated $2 \mathrm{~h}$ in a biotinylated, affinity-purified, swine anti-rabbit IgG secondary antibody (1:200 dilution; catalog \#E0353; DakoCytomation, Carpinteria CA) and then washed again for $30 \mathrm{~min}$ in PBST. At the beginning of the 30 min wash in PBST, an avidin-biotin complex solution was prepared from a Vector Laboratories (Burlingame, CA) kit as recommended (catalog \#PK-6100). Briefly, the avidin and the biotin were added to PBST as a 1:140 dilution and placed on an orbital shaker for $30 \mathrm{~min}$. Just before use, the avidin-biotin solution was further diluted to a 1:500 final concentration. The tissue was then incubated $1.5 \mathrm{~h}$ in the avidin-biotin complex solution. The tissue was then washed in PBST for $20 \mathrm{~min}$ and then PB for $10 \mathrm{~min}$. The chromogen solution was prepared as recommended by Vector Laboratories with slate gray (cata$\log$ \#SK-4700; Vector Laboratories) as the substrate. The sections were incubated with the chromogen solution for $5 \mathrm{~min}$. All sections were mounted on glass slides, dried overnight, dehydrated, and coverslipped using DPX mounting medium (catalog \#13512; Electron Microscopy Sciences, Ft. Washington, PA).

Preadsorptions were done to confirm the specificity of the $\mathrm{AT}_{1} \mathrm{R}$ antibody for the $\mathrm{AT}_{1 \mathrm{~A}}$ Rs and $\mathrm{AT}_{1 \mathrm{~B}}$ Rs. To preadsorb the $\mathrm{AT}_{1} \mathrm{R}$ antibody, a 1:500 dilution of the $\mathrm{AT}_{1} \mathrm{R}$ antibody was incubated overnight at room temperature in $1 \mathrm{ml}$ of PBST alone or with $10 \times$ or $20 \times$ concentrations of the $\mathrm{AT}_{1 \mathrm{~A}} \mathrm{R}$ and $\mathrm{AT}_{1 \mathrm{~B}} \mathrm{R}$ peptides (generously provided by Dr. Robert Speth). The following day, standard immunohistochemistry procedures were used as stated previously in Materials and Methods before incubating rat brain sections with the $\mathrm{AT}_{1} \mathrm{R}$ antibody-peptide solutions.

Photomicrographs were obtained using a Leica (Nussloch, Germany) bright-field microscope using N plan $5 \times, 10 \times, 20 \times$, and $40 \times$ objective lenses (model DMLB; Leica), a SPOT digital camera (RT color; Diagnostics Instruments, Sterling Heights, MI), and SPOT 4.0.6 for Windows digital imaging software (Silicon Graphics, Mountain View, CA). Photographic plates were prepared in CorelDraw (Eden Prairie, MN) 11.633 for Windows.

\section{Western blotting and preadsorption of $A T_{1} R$ antibody}

To preadsorb the antibody, a 1:500 dilution of the $\mathrm{AT}_{1} \mathrm{R}$ antibody was incubated overnight at room temperature in $1 \mathrm{ml}$ of $0.1 \mathrm{M}$ PBS with $0.1 \%$ Tween 20 alone or with $5 \times, 10 \times$, or $20 \times$ concentrations of $\mathrm{AT}_{1 \mathrm{~A}} \mathrm{R}$ and $\mathrm{AT}_{1 \mathrm{~B}} \mathrm{R}$ peptides. The following day, $50 \mathrm{mg}$ of nonfat dry milk was then added to each $1 \mathrm{ml}$ and used in the Western blotting procedure.

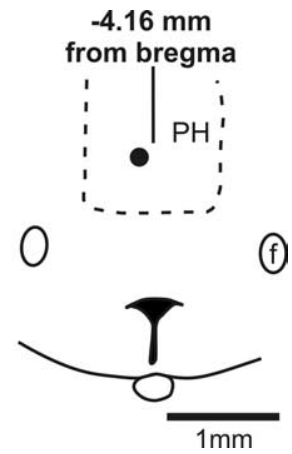

Forty micrograms of rat brain lysate was run on a $10 \%$ SDS-PAGE minigel. Gels were transferred to nitrocellulose membrane (catalog \#10-402-588, Protran; Schleicher \& Schuell, Keene, $\mathrm{NH}$ ) and stained in Ponceau stain (catalog \#P3504; Sigma) to check for even protein loading. After blocking the membranes overnight in 5\% milk PBS/0.1\% Tween 20, membranes were washed with $\mathrm{PBS} / 0.1 \%$ Tween 20 , probed with the $1 \mathrm{ml}$ antibody/peptide mixtures, washed with PBS/0.1\% Tween 20, probed with a secondary goat anti-rabbit IgG-HRP antibody (1:2000 dilution; catalog \#SC-2004; Santa Cruz Biotechnology, Santa Cruz, CA), and again washed with PBS/0.1\% Tween 20. Membranes were developed with ECL Detection Reagent (catalog \#RPN2109; Amersham Biosciences, Piscataway NJ) and exposed to Kodak BioMax MR film (catalog \#870-1302; Fisher Scientific, Pittsburgh, PA) for $\sim 7 \mathrm{~min}$.

\section{Measurement of glutamic acid decarboxylase activity}

The radiometric assay for GAD (Shekhar et al., 1996), modified from Bostwick and Le (1991), was based on supplying the enzyme with glutamate (substrate) with a ${ }^{14} \mathrm{C}$-labeled carboxyl group and measuring the liberated ${ }^{14} \mathrm{CO}_{2}$. The brain tissue ipsilateral to the L-AG infusion, compared with the control site contralateral to the L-AG infusion, was homogenized with $20 \mathrm{vol}$ of a solution containing EDTA (1 mM), Triton $\mathrm{X}-100(0.2 \% \mathrm{v} / \mathrm{v})$, and aminoethanolthiol $(1 \mathrm{~mm})$ in phosphate buffer, $\mathrm{pH}$ 7. Each well of tissue culture plate (catalog \#3070; Falcon, Franklin Lakes, NJ) received $10 \mu \mathrm{l}$ of tissue homogenate or blank (in triplicates) and $10 \mu \mathrm{l}$ buffer substrate, after which the plate was covered with a $14 \times$ $11 \mathrm{~cm}$ sheet of gel blot paper, latched shut, incubated in a $37^{\circ} \mathrm{C}$ water bath for $30 \mathrm{~min}$, and then transferred to a $60^{\circ} \mathrm{C}$ bath for $45 \mathrm{~min}$, and the trapped ${ }^{14} \mathrm{CO}_{2}$ was measured as described previously (Bostwick and Le, 1991).

\section{Experimental procedures}

After $4 \mathrm{~d}$ recovery from Alzet pump implantation, the following experimental procedures were conducted

Effects of microinjection of losartan into the DMH on panic-like response evoked by intravenous lactate. In one group of rats implanted with unilateral L-AG Alzet minipumps into the DMH $(n=8)$, the panic-like exaggerated HR, BP, and SI responses to lactate infusions were obtained on post-pump day 4 to establish that the rats that had L-AG pumps had become behaviorally and physiologically responsive to lactate. Respiration rate was not obtained because of problems with Dataquest software (Data Science International). On post-pump days 6, 8, 10, and 12, two rats each from this group were injected first with either vehicle [artificial CSF (aCSF)] or with one of the doses of losartan $(10$ or $100 \mathrm{pmol} / 100 \mathrm{nl}$ or $250 \mathrm{pmol} / 200 \mathrm{nl}$; generously provided by Merck, Darmstadt, Germany) into the DMH through the vertical arm of the T-shaped pump cannula. At $\sim 10$ min later, animals were given intravenous lactate infusions as described previously, and the HR and BP responses were recorded. Thus, two rats each were given vehicle or one of the doses of losartan injections into the DMH on day 6 , whereas on days 8,10 , and 12 , they received the remaining injections for their assigned group in a counterbalanced design. After the experiment, the animals were killed and tissue was processed as noted below.

Effects of microinjection of saralasin into the DMH on panic-like response evoked by intravenous lactate. In one group of rats implanted with unilateral L-AG Alzet minipumps into the DMH $(n=8)$, the panic-like exaggerated HR, BP, RR, and SI responses to lactate infusions were obtained on post-pump day 4 to establish that the rats that had L-AG pumps had become behaviorally and physiologically responsive to lactate. On postpump days $6,8,10$, and 12 , two rats each from this group were injected first with either vehicle (aCSF) or with one of the doses of saralasin (10, 100 , and $250 \mathrm{pmol} / 100 \mathrm{nl}$; catalog \#A2275; Sigma) into the DMH as described previously. At $\sim 10$ min later, animals were given intravenous 
lactate infusions as described previously, and the HR, BP, RR, and SI responses were recorded. Thus, two rats each were given vehicle or one of the doses of saralasin injections into the DMH on day 6 , whereas on days 8,10 , and 12 , they received the remaining injections for their assigned group in a counterbalanced design. After the experiment, the animals were killed and tissue was processed as noted below.

Effects of microinjection of saralasin outside the DMH on panic-like response evoked by intravenous lactate. The rats implanted with unilateral L-AG Alzet minipumps into the DMH and ipsilateral chronic microinjection cannulas 2 $\mathrm{mm}$ away from the DMH $(n=6)$ were used for this study. The HR, BP, RR, and SI responses of these rats to lactate infusions were obtained on post-pump day 4 as described previously to establish that the rats had become responsive to lactate. In a counterbalanced design, on postpump day 6 , half of the group was injected first with vehicle (aCSF) and the others were injected with the $250 \mathrm{pmol} / 100 \mathrm{nl}$ dose of saralasin into the area $2 \mathrm{~mm}$ away from the DMH as described previously. At $\sim 10$ min later, animals were given intravenous lactate infusions as described previously, and their HR, BP, RR, and SI responses were recorded. On post-pump day 8 , the animals received the remaining injection of either vehicle or saralasin $(250 \mathrm{pmol})$ into the area lateral to the $\mathrm{DMH}$ and were rechallenged with intravenous lactate, and their HR, BP, RR, and SI responses were recorded.

Effects of microinjection of saralasin into the DMH on panic-like response evoked by intravenous yohimbine. The rats implanted with unilateral L-AG Alzet minipumps into the $\mathrm{DMH}(n=$ 4) were used for this study. The HR, BP, and RR responses of these rats to lactate infusions were obtained on post-pump day 4 as described previously to establish that the rats had become responsive to lactate. In a counterbalanced design, on post-pump day 6 , half of the group was injected first with vehicle (aCSF), and the others were injected with the $250 \mathrm{pmol} / 100 \mathrm{nl}$ dose of saralasin into the DMH as described previously. At $\sim 10$ min later, animals were given intravenous infusions of a different panic-producing agent, the $\alpha$-2 adrenergic antagonist yohimbine $(0.4 \mathrm{mg} / \mathrm{kg})$, as described previously (Charney et al., 1984), and their HR, BP, and RR responses were recorded. Social interaction tests were not performed.

Selectivity of saralasin: comparison of effect on A-II- and NMDA-mediated stimulation of the $D M H$. Two groups of rats implanted with unilateral L-AG Alzet minipumps into the DMH $(n=4$ each) were first challenged with intravenous lactate infusions on postoperative day 4 to establish that the rats had become more anxious and responsive to lactate. On post-pump day 6 , the obturators covering the top of the Alzet pump cannulas were removed, and an injection cannula was introduced into the guide cannulas. The first group of rats were injected, in a counterbalanced design and separated by at least $60 \mathrm{~min}$, with two doses of A-II ( 20 and $100 \mathrm{pmol})$ directly into the $\mathrm{DMH}$ as described previously. In the second group of rats, saralasin $(250 \mathrm{pmol} / 100 \mathrm{nl})$ was microinjected into the DMH. At $\sim 10$ min later, in a counterbalanced design, half of the animals received microinjections of either NMDA (20 pmol/100 nl) or A-II ( $100 \mathrm{pmol} / 100$ $\mathrm{nl}$ ) into the $\mathrm{DMH}$, and the resulting $\mathrm{HR}, \mathrm{BP}$, and $\mathrm{RR}$ responses were
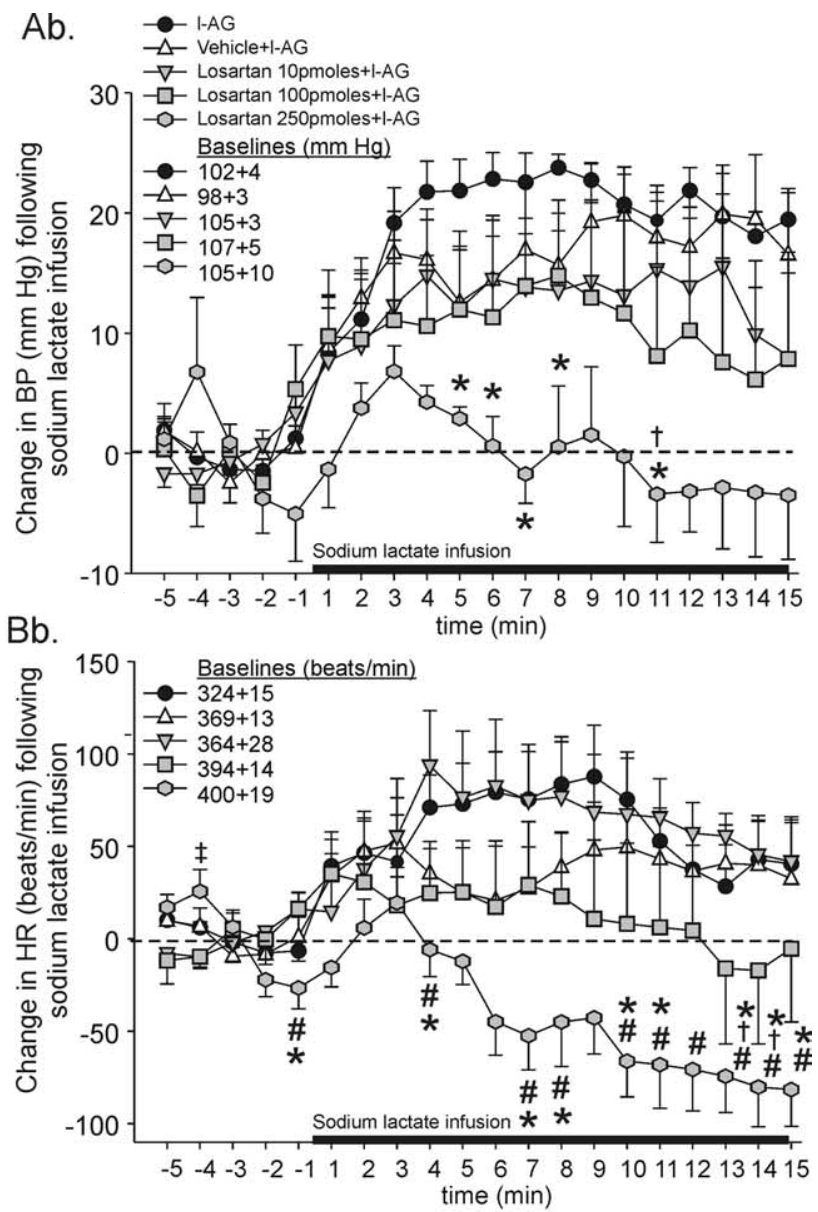

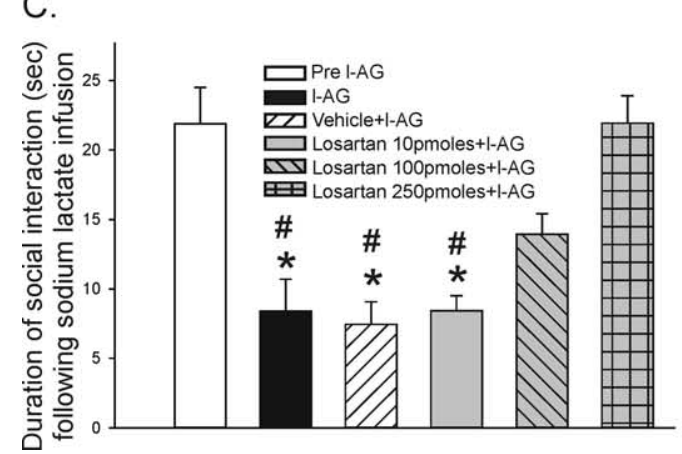

Figure 2. Changes in BP ( $\boldsymbol{A} \boldsymbol{a}$, peak height; $\boldsymbol{A} \boldsymbol{b}$, change from baseline), $H R$ ( $\boldsymbol{B} \boldsymbol{a}$, peak height; $\boldsymbol{B} \boldsymbol{b}$, change from baseline), and the duration of $S \mathrm{I}$ time $(C)$ after intravenous infusions of sodium lactate $(10 \mathrm{ml} / \mathrm{kg}$ of $0.5 \mathrm{~N}$ solution) in rats that were implanted unilaterally with Alzet minipumps infusing the GABA synthesis inhibitor L-AG into the DMH. On post-pump days 6, 8, 10, and 12, rats were injected, in counterbalanced order, with a dose of either losartan (10, 100 , or $250 \mathrm{pmol}$ in $100 \mathrm{nl}$ ) or vehicle (aCSF) into the DMH before intravenous lactate infusions. Losartan dose-dependently reduced the lactate-induced responses. There were no significant differences in baseline HR or BP between any of the groups (numbers adjacent to graphs on $\boldsymbol{A} \boldsymbol{b}$ and $\boldsymbol{B} \boldsymbol{b}$ ). Data are presented as mean \pm SEM. $p<0.05$, significantly different: ${ }^{*}$, compared with L-AG + lactate; $\dagger$, compared with L-AG + lactate + aCSF vehicle; and \#, compared with L-AG + lactate + losartan (10 pmol; two-way ANOVA with Tukey's test).

recorded. At $\sim 48 \mathrm{~h}$ later, they were reinjected with saralasin $(250 \mathrm{pmol})$ into the $\mathrm{DMH}$ and $10 \mathrm{~min}$ later were given the remaining drug microinjection (20 pmol of NMDA or 100 pmol of A-II) as before. Social interaction tests were not performed.

Postexperimental tissue processing. After the losartan experiment, rats were anesthetized by placing them in a closed Plexiglas box that was connected to an isoflurane system (MGX Research Machine; Vetamic). For the losartan experiment, rats were then killed, and their brains were removed and then frozen and cut at $30 \mu \mathrm{m}$ on a cryostat to visualize the injection/infusion sites. After all other experiments, rats were killed and the brains were removed. The brains were then frozen and cut with an 

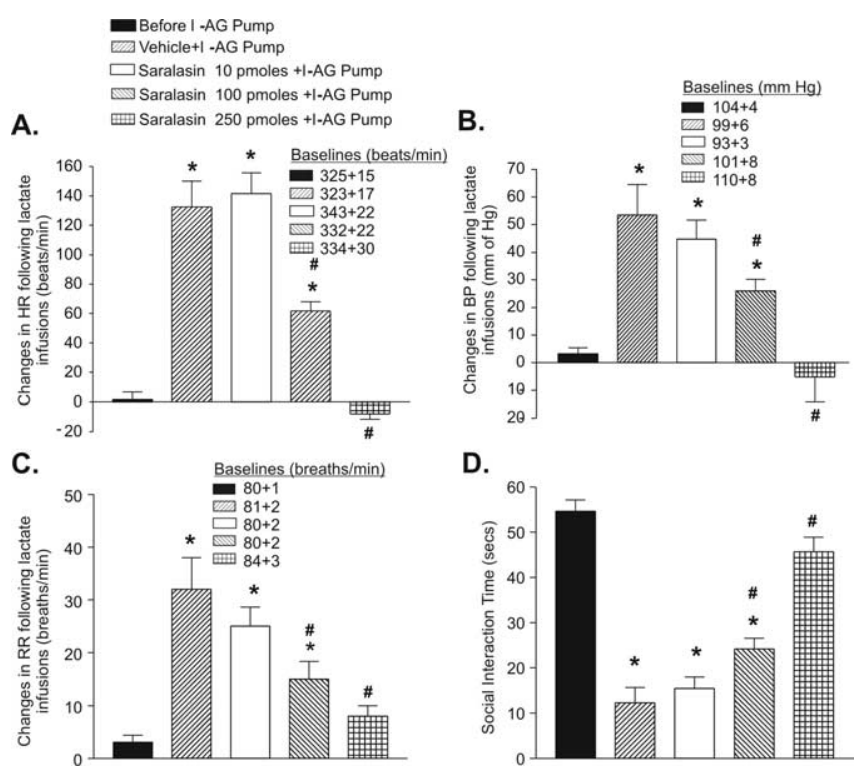

D.

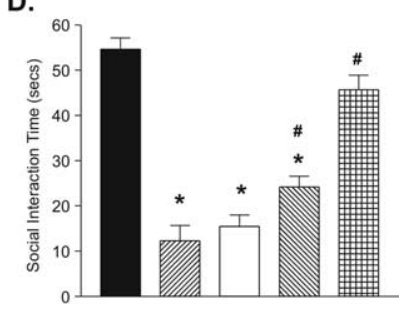

Figure 3. Changes in $\mathrm{HR}(\boldsymbol{A}), \mathrm{BP}(\boldsymbol{B}), \operatorname{RR}(\boldsymbol{C})$, and SI (D) after intravenous infusions of sodium lactate (10 ml/kg of $0.5 \mathrm{~N}$ solution) in rats that were implanted unilaterally with Alzet minipumps infusing the GABA synthesis inhibitor L-AG into the DMH. On post-pump days 6,8 , 10 , and 12 , rats were injected, in counterbalanced order, with a dose of either saralasin $(10,100$, or $250 \mathrm{pmol}$ in $100 \mathrm{nl}$ ) or vehicle (aCSF) into the DMH before intravenous lactate infusions. Saralasin dose-dependently reduced the lactate-induced responses. There were no significant differences in baseline HR, BP, or RR (numbers adjacent to graphs) between any of the groups. Data are presented as mean \pm SEM. $p<0.05$, significantly different: ${ }^{*}$, compared with before L-AG pumps; and\#, compared with vehicle in the DMH (two-way ANOVA with Bonferroni's test).

adult rat brain matrix ( $1 \mathrm{~mm}$ coronal sections; Zivic-Miller Laboratories, Zelienople, PA) as described previously (Shekhar et al., 1996), and the injection site was verified. The brain section containing the DMH was microdissected, weighed, and stored in a $-70^{\circ} \mathrm{C}$ freezer until assayed. At a later date, tissue levels of the GABA synthetic enzyme GAD were determined using procedure modified from Bostwick and Le (1991) as reported previously (Shekhar et al., 1996).

Data analysis. All data were expressed as mean \pm SEM. When comparing two or more means of different groups, either a two-way ANOVA with Bonferroni's post hoc test or repeated-measures ANOVA with Tukey's post hoc test were used to test differences between means when repeated measurements were made. A paired $t$ test was used when comparing means of two measures in the same animals. Statistical significance was accepted with $p<0.05$.

\section{Results}

Determination of injection sites and assessment of effect of chronic infusion of $\mathrm{L}-\mathrm{AG}$ on GAD activity in the DMH

The DMH is approximately square in dimension with the corners being the mammillothalamic tract, the fornix, the top of the third ventricle, and the halfway down the third ventricle (immediately medial from the fornix) (Fig. 1). The DMH, as described, is particularly sensitive to BMI-induced cardioexcitatory response (Samuels et al., 2004), receives projections from CVOs (Thompson and Swanson, 1998), and has selective neurochemical changes after stress (Lowry et al., 2003). Examination of brain sections confirmed that pumps were properly implanted for chronic microinfusion into the DMH in all of the animals used in the final data analysis of saralasin experiments and that microinjection cannulas were appropriately placed lateral to the $\mathrm{DMH}$ (i.e., LH) in anatomical control experiments (Fig. 1). All implantation sites for losartan experiments resided in the $\mathrm{DMH}$, except one that was located just caudal to the DMH (Fig. 1) and is a region that is also known to be cardioexcitatory (Shekhar and
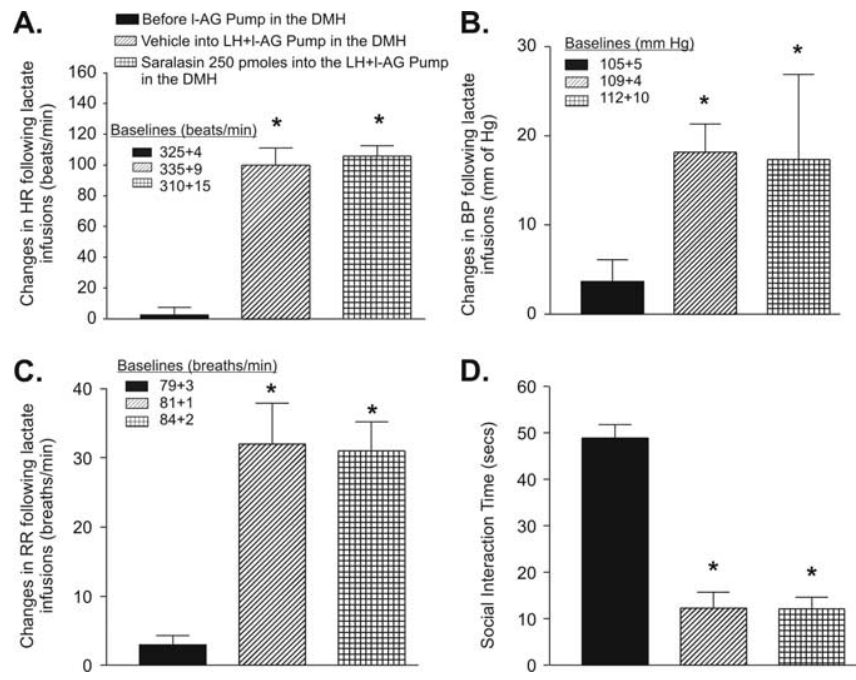

Figure 4. Changes in $\mathrm{HR}(\boldsymbol{A}), \mathrm{BP}(\boldsymbol{B}), \operatorname{RR}(\boldsymbol{C})$, and $\mathrm{SI}(\boldsymbol{D})$ after intravenous infusions of sodium lactate in rats that were implanted unilaterally with $\mathrm{L}-\mathrm{AG}$ minipumps into the DMH. On postpump days 6 and 8 , rats were injected with either saralasin ( $250 \mathrm{pmol}$ in $100 \mathrm{nl}$ ) or vehicle (aCSF) into the $\mathrm{LH}$, which is $2 \mathrm{~mm}$ lateral from the DMH before intravenous lactate infusions. Saralasin in the LH did not change the lactate-induced responses. There were no significant differences in baseline HR, BP, or RR between any of the groups (numbers adjacent to graphs). Data are presented as mean \pm SEM. ${ }^{*} p<0.05$, significantly different compared with before $\mathrm{L}-\mathrm{AG}$ pumps in the DMH (two-way ANOVA with Bonferroni's test.).

Keim, 1997; Samuels et al., 2004). All cannula implantations were also physiologically verified by injecting BMI under anesthesia and obtaining increases in HR of at least 50 beats/min.

GAD activity in the DMH assessed at the end of the experiment was significantly decreased on the pump-implanted side $(504 \pm 40 \mathrm{pmol} / \mathrm{mg}$ protein for $30 \mathrm{~min}$ ) compared with the contralateral side (data not shown) $(t=10.8$; df $=17$; $p<0.0001$, paired $t$ test) (for illustration of area, see Fig. 1).

\section{Effects of microinjection of losartan into the DMH on panic-} like response evoked by intravenous lactate

On day 4 after implantation of L-AG Alzet pumps, intravenous infusion of sodium lactate after microinjection of aCSF into the $\mathrm{DMH}$ produced in all rats a typical panic-like response characterized by significant increases in HR and BP (Fig. $2 A a, A b, B a, B b$, respectively) (aCSF + lactate $+\mathrm{L}-\mathrm{AG}$, Tukey's post hoc tests, $p<$ 0.05). Microinjection of the highest dose of losartan, an $A_{1} R$ antagonist, into the $\mathrm{DMH}$ blocked peak tachycardia responses $(F=3.4 ; \mathrm{df}=4,18 ; p<0.04$, Tukey's post hoc test) $5-15 \mathrm{~min}$ after lactate (Fig. $2 \mathrm{Ba}$ ). Previous injections of the highest dose of losartan also reduced the duration of sodium lactate-induced hypertensive (treatment effect, $F=3.4$, df $=4,18, p<0.04$; treatment $\times$ time effect, $F=1.5 ; \mathrm{df}=76,342, p<0.01)$ and tachycardia (treatment effect, $F=3.6$, df $=4,18, p<0.001$; treatment $\times$ time effect, $F=2.4$, df $=76,342, p<0.03)$ and increased the duration of SI responses (treatment effect, $F=12.1$; $\mathrm{df}=5,22 ; p<0.001$ ) in L-AG treated rats (Fig. $2 A b, B b, C$, respectively). Significant differences between treatment groups were noted at multiple time points for HR and mean arterial BP (Fig. $2 A b, B b$, respectively) (Tukey's post hoc tests, $p<0.05$ ). The mean baseline values ( $1 \mathrm{~min}$ before infusion of sodium lactate) for each treatment group are listed in Figure 2, $A b$ and $B b$. No significant differences were noted for baseline measures of $\mathrm{HR}(F=2.4$; $\mathrm{df}=$ $4,18 ; p=0.085)$ or $\mathrm{BP}(F=0.4 ; \mathrm{df}=4,18 ; p=0.776)$ between treatment groups. 
Effects of microinjection of saralasin into the DMH on panic-like response evoked by intravenous lactate

When rats were tested at baseline before pump implantation, intravenous lactate infusions produced no significant changes in $\mathrm{HR}, \mathrm{BP}, \mathrm{RR}$, or SI (Fig. $3 A-D$, Baselines). On day 4 after implantation of L-AG Alzet pumps, intravenous infusion of sodium lactate after microinjection of aCSF into the DMH produced in all rats a typical panic-like response characterized by significant increases in $\mathrm{HR}, \mathrm{BP}, \mathrm{RR}$, and SI (Fig. $3 A, B, C, D$, respectively) (aCSF + lactate + L-AG, Bonferroni's post hoc tests, $p<0.05)$. When the response to lactate infusion was retested under different treatment conditions, there were significant differences for the changes in $\operatorname{HR}(F=$ $42.5 ; \mathrm{df}=4,29 ; p<0.0001), \mathrm{BP}(F=5.6$; $\mathrm{df}=4,29 ; p<0.01), \mathrm{RR}(F=22.6 ; \mathrm{df}=4,29 ; p<0.0001)$, and SI $(F=65.8 ; \mathrm{df}=4,29 ; p<0.0001)$. Previous injection of saralasin into the DMH elicited dose-dependent suppression of all components of the response to subsequent infusion of sodium lactate (Bonferroni's post hoc test, $p<0.05$ between saralasin doses) (Fig. $3 A-D)$. Thus, microinjection of a nonselective A-II receptor antagonist into the DMH could completely suppress all components of the physiological and behavioral response to intravenous infusion of lactate in these rats.

The mean baseline values ( 1 min before infusion of sodium lactate) for each treatment are listed in Figure $3 A-C$. No significant differences were noted for baseline measures of $\mathrm{HR}(F=0.1$; $\mathrm{df}=4,25 ; p=0.972), \mathrm{BP}(F=1.0 ; \mathrm{df}=4,25 ; p=0.431)$, or $\mathrm{RR}$ $(F=0.7 ; \mathrm{df}=4,24 ; p=0.570)$ between treatment groups.

\section{Effects of microinjection of saralasin outside the DMH on intravenous lactate-induced panic-like responses}

In rats that had L-AG pumps implanted in the DMH and microinjection cannulas placed in a region $2 \mathrm{~mm}$ lateral to the $\mathrm{DMH}$, intravenous infusion of sodium lactate $4 \mathrm{~d}$ after pump implantation evoked changes similar to those described above, including significant increases in HR (repeated measures ANOVA; $F=54.2 ; \mathrm{df}=$ $2,17 ; p<0.001), \mathrm{BP}(F=7.62 ; \mathrm{df}=2,17 ; p<0.01), \mathrm{RR}(F=26.57$; $\mathrm{df}=2,17 ; p<0.001)$, and SI $(F=106.3 ; \mathrm{df}=2,17 ; p<0.0001)$ (Fig. $4 A-D)$. Unlike identical microinjections into the $\mathrm{DMH}$, injection of the highest dose of saralasin $(250 \mathrm{pmol})$ into sites lateral to the DMH failed to alter the HR, BP, RR, or SI responses to subsequent infusion of lactate ( post hoc Bonferroni's test, $p>0.05$ ) (Fig. $4 A-D$ ).

The mean baseline values ( $1 \mathrm{~min}$ before infusion of sodium lactate) for each treatment group are listed in Figure $4 A-C$. No significant differences were noted for baseline measures of HR $(F=1.5 ; \mathrm{df}=2,15 ; p=0.266), \mathrm{BP}(F=0.2 ; \mathrm{df}=2,15 ; p=0.782)$, or $\mathrm{RR}(F=1.5 ; \mathrm{df}=2,15 ; p=0.248)$ between treatment groups.

\section{Effect of microinjection of saralasin into the DMH on} yohimbine-induced panic-like responses

In separate groups of rats with pumps implanted, injection of the highest dose of saralasin (250 pmol) into the DMH by itself had no significant effects of $\mathrm{HR}, \mathrm{BP}$, or RR. In these rats, intravenous administration of yohimbine produced a typical panic-like response consisting of significant increases in HR (paired $t$ test; $t=$ 6.67; $\mathrm{df}=3 ; p<0.01), \mathrm{RR}(t=9.13 ; \mathrm{df}=3 ; p<0.003)$, and $\mathrm{BP}$ $(t=12.4 ; \mathrm{df}=3 ; p<0.002)$ (Fig. $5 A-C$, respectively). Identical
B.

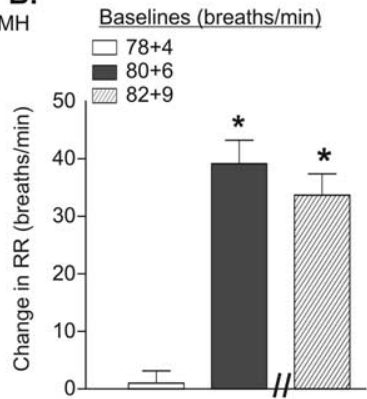

C.

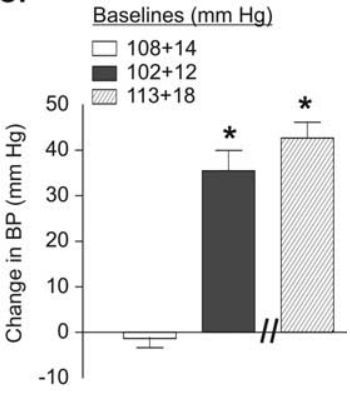

treatment with yohimbine after microinjection of saralasin 250 pmol into the DMH resulted in increases that were not significantly different from those seen in untreated rats.

The mean baseline values ( 1 min before infusion of sodium lactate) for each treatment group are listed in Figure $5 A-C$. No significant differences were noted for baseline measures of BP $(F=0.2 ; \mathrm{df}=2,15 ; p=0.784), \mathrm{HR}(F=0.6 ; \mathrm{df}=2,15 ; p=$ $0.568)$, or RR $(F=0.1 ; \mathrm{df}=2,12 ; p=0.939)$ between treatment groups.

\section{Comparison of effect of microinjection of saralasin into the $\mathrm{DMH}$ on responses to direct local neuronal stimulation with NMDA and with A-II}

To assess the specificity of the action of saralasin, we compared the effect of previous microinjection of the antagonist into the $\mathrm{DMH}$ on the responses evoked by subsequent microinjection of A-II and of the glutamate receptor agonist NMDA in rats with implanted L-AG pumps. Lactate infusions in this group of rats also elicited significant changes in $\mathrm{HR}, \mathrm{RR}$, and $\mathrm{BP}$ as described above (Fig. 6A-C) (lactate, post hoc Bonferroni's test, $p<0.01$ ). Direct injection of A-II into the DMH of the panic-prone rats resulted in a dose-dependent increases in $\mathrm{HR}, \mathrm{RR}$, and BP similar to those observed after lactate infusions (Fig. 6A-C). Previous local microinjection of saralasin into the DMH significantly reduced the effect of the highest dose of A-II (100 pmol) injections on $\operatorname{HR}(F=75.39 ; \mathrm{df}=2,11 ; p<0.001)$, RR $(F=43.99 ; \mathrm{df}=$ $2,11 ; p<0.001)$, and BP $(F=26.02 ; \mathrm{df}=2,11 ; p<0.002)$ responses within this group

However, unlike the increases in HR and BP elicited by A-II that were blocked by previous microinjection of saralasin, the $\mathrm{HR}, \mathrm{RR}$, or BP responses were still elicited by local microinjection of NMDA (Tukey's post hoc test, $p<0.01$ ) (Fig. $6 A-C$ ). These increases in $\mathrm{HR}, \mathrm{RR}$, and $\mathrm{BP}$ elicited by NMDA after saralasin were similar to the changes elicited in another group of rats with L-AG pumps given injections of NMDA $20 \mathrm{pmol}$ alone into the $\mathrm{DMH}$, which resulted in increases of $\mathrm{HR}, \mathrm{RR}$, and $\mathrm{BP}(n=3)$ (Fig. 6A-C).

The mean baseline values ( 1 min before infusion of sodium lactate) for each treatment group are listed in Figure $6 A-C$. No significant differences were noted for baseline measures of $\operatorname{HR}(F=0.4$; $\mathrm{df}=6,20 ; p=0.860), \mathrm{RR}(F=0.2 ; \mathrm{df}=6,18 ; p=0.954)$, or BP $(F=$ $0.1 ; \mathrm{df}=6,18 ; p=0.993)$ between treatment groups. 
$\square$ I-AG pump+lactate infusions i.v.

$\square$ I-AG pump+Saline into $\mathrm{DMH}$

यII I-AG pump+All 20 pmoles into $\mathrm{DMH}$

I-AG pump+A-II 100 pmoles into $\mathrm{DMH}$

WII I-AG pump+Saralasin 250 pmoles+A-II 100 pmoles into DMH

I-AG pump+Saralasin 250 pmoles+NMDA 20 pmoles into DMH

I-AG pump+NMDA 20 pmoles into DMH

A.
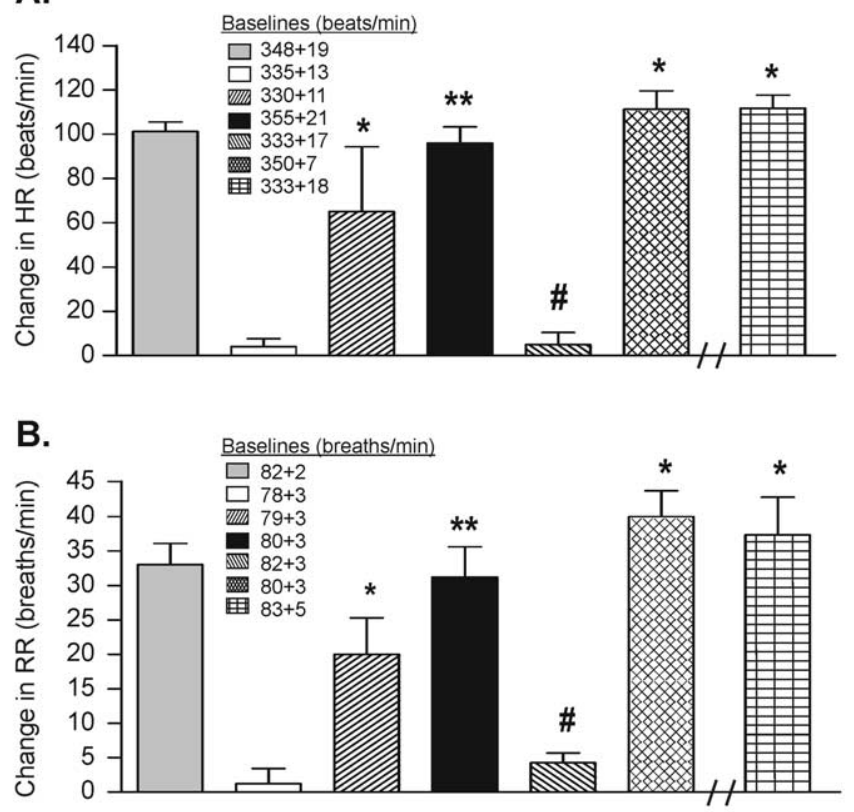

C.

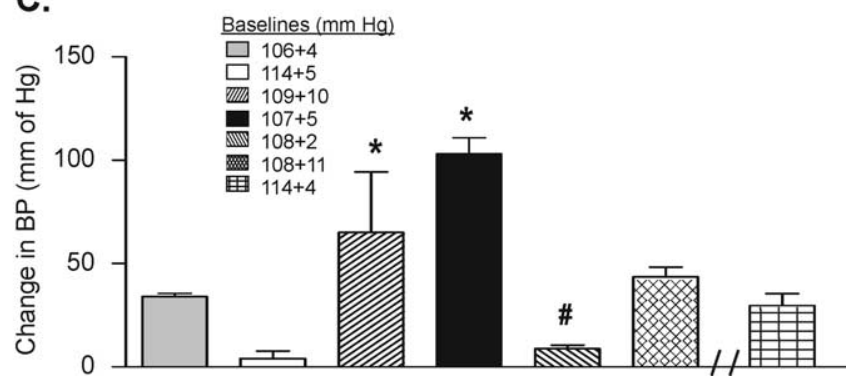

Figure 6. Changes in $\operatorname{HR}(\boldsymbol{A}), \operatorname{RR}(\boldsymbol{B})$, and $\mathrm{BP}(\boldsymbol{C})$ after direct microinjections of two doses of A-II into the DMH or A-II and NMDA injections preceded by saralasin injections into DMH of rats implanted unilaterally with L-AG minipumps into the DMH. Physiological responses after intravenous infusions of sodium lactate ( $10 \mathrm{ml} / \mathrm{kg}$ of $0.5 \mathrm{~N}$ solution) were assessed in these rats $4 \mathrm{~d}$ after pump implantations. One group was injected with the two doses of A-II ( 20 or $100 \mathrm{pmol}$ ) into the DMH in a counterbalanced design. In the other group, on post-pump days 6 and 8, rats were injected, in a counterbalanced order, with either saralasin ( $250 \mathrm{pmol}$ in $100 \mathrm{nl})$ followed by A-II (100 pmol/100nl) into the DMH or saralasin followed by NMDA (20 pmol/100 nl) injections. Another group of L-AG-treated rats received NMDA $(20 \mathrm{pmol} / 100 \mathrm{nl})$ injections into the DMH. There were no significant differences in baseline $H R, B P$, or RR between any of the groups (numbers adjacent to graphs). Data are presented as mean \pm SEM. ${ }^{*} p<0.05$, significantly different from L-AG pump + saline into the DMH; ${ }^{* *} p<0.05$, ANOVAs with Tukey's post hoc tests.

\section{Characterization of the $\mathrm{AT}_{1} \mathrm{R}$ antibody and} immunohistochemical demonstration of the $\mathrm{AT}_{1} \mathrm{R}$ in the $\mathrm{DMH}$ Western blotting for the $\mathrm{AT}_{1} \mathrm{R}$ in adult rat brain lysate revealed that the $\mathrm{AT}_{1} \mathrm{R}$ produced higher signals when either the concentration of the lysate or antibody was increased (Fig. 7A) and that the signal was at $\sim 45 \mathrm{kDa}$, which is consistent with previous estimations of the molecular weight of the $\mathrm{AT}_{1} \mathrm{R}$ (Hoffmann and Cool, 2003; Imanishi et al., 2003). Previous preadsorption of the
$\mathrm{AT}_{1} \mathrm{R}$ antibody with either $10 \times$ or $20 \times$ concentration of an $\mathrm{AT}_{1 \mathrm{~A}} \mathrm{R}$ and $\mathrm{AT}_{1 \mathrm{~B}} \mathrm{R}$ mixture eliminated the $\mathrm{AT}_{1} \mathrm{R}$ Western blot signal in adult rat brain lysate (Fig. $7 B$ ). Furthermore, previous preadsorption of the $\mathrm{AT}_{1} \mathrm{R}$ antibody with either $10 \times$ or $20 \times$ concentration of an $\mathrm{AT}_{1 \mathrm{~A}} \mathrm{R}$ and $\mathrm{AT}_{1 \mathrm{~B}} \mathrm{R}$ mixture eliminated $\mathrm{AT}_{1} \mathrm{R}$ immunostaining in the DMH (Fig. $7 I, J$ ) and $\mathrm{LH}$, as well as in the arcuate nucleus, supraoptic nucleus, and paraventricular hypothalamic nucleus (data not shown) of adult male rat brain sections. Overall, These data support the notion that the primary antibody used was immunostaining the $\mathrm{AT}_{1} \mathrm{R}$ antigen. The results of the immunostaining are represented in Figure $7 D-G$ and clearly demonstrate the presence of $\mathrm{AT}_{1} \mathrm{Rs}$ on cell bodies and fibers in the $\mathrm{DMH}, \mathrm{LH}$, and median eminence, which is consistent with previous data describing $\mathrm{AT}_{1} \mathrm{R}$ mRNA (Lenkei et al., 1995, 1998) and protein in the adult male rat brain (Giles et al., 1999). In addition, we also detected $\mathrm{AT}_{1}$ Rs on cell bodies in CVOs such as the SFO and in other regions of the hypothalamus [i.e., the paraventricular hypothalamic nucleus and median preoptic area (MPOA); data not shown], which is also consistent with previous findings (Lenkei et al., 1995, 1998; Giles et al., 1999).

\section{Discussion}

Sodium lactate infused intravenously $(10 \mathrm{ml} / \mathrm{kg})$ elicited robust panic-like responses in rats with chronic inhibition of GABA synthesis in the DMH region (i.e., panic-prone rats), confirming our previous reports about this animal model of panic disorder (Shekhar et al., 1996; Shekhar and Keim, 1997, 2000). Injecting the $\mathrm{AT}_{1} \mathrm{R}$ antagonist losartan or the nonspecific A-II receptor antagonist saralasin, but not vehicle, into the $\mathrm{DMH}$ attenuated or blocked lactate-induced panic-like responses, respectively. The effect of saralasin was specific to the DMH, because injecting the highest dose of saralasin into an area lateral to the DMH did not alter lactate-induced panic-like responses. Furthermore, blockade of A-II receptors with saralasin appears to be specific for suppressing panic-like responses evoked by lactate infusion because this treatment failed to inhibit the similar effects produced by intravenous infusions of the adrenergic panicogenic agent yohimbine. The action of saralasin in the $\mathrm{DMH}$ also appeared to represent a specific blockade of A-II receptors in the DMH because it selectively blocked the effects of direct injections of A-II but not the glutamate agonist NMDA, suggesting that the paniclike responses can still occur as a result of activation of non-A-IImediated stimuli in the DMH. Thus, our findings support a role for A-II receptors in the DMH mediating the generation of paniclike response in these lactate-sensitive rats.

To our knowledge, this is the first study to implicate the hypothalamic A-II system in the pathophysiology of panic disorder. Although much of the previous studies have focused on the cardiovascular and hormonal functions of A-II (Van de Kar and Blair, 1999), there is increasing evidence that A-II mechanisms in the brain are involved in a wide range of cognitive and emotional processes (Saavedra et al., 2004; Saavedra, 2005). Recent studies have reported that blockade of $\mathrm{AT}_{1} \mathrm{R}$ has anxiolytic effects (Saavedra et al., 2006), blocks the hypothalamic-pituitary-adrenal responses to isolation stress (Armando et al., 2001), reduces stress-induced release of catecholamines (Baiardi et al., 2004), attenuates stress-associated gastric ulcers (Bregonzio et al., 2003), selectively regulates autonomic responses to stress but not feeding (De Matteo et al., 2006), and blocks the stress-mediated changes in the corticotrophin releasing factor (CRF) and benzodiazepine receptors (Saavedra et al., 2006). Based on such findings, it has been suggested that A-II receptor-selective drugs may be a novel approach to treating stress and anxiety disorders 


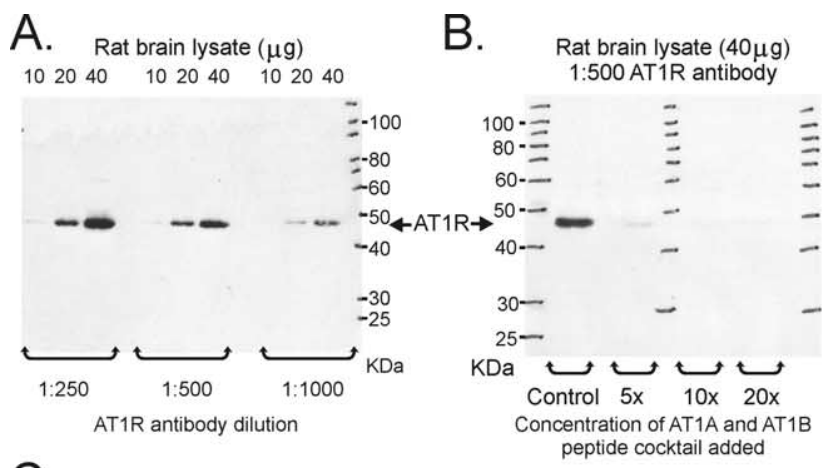

C.

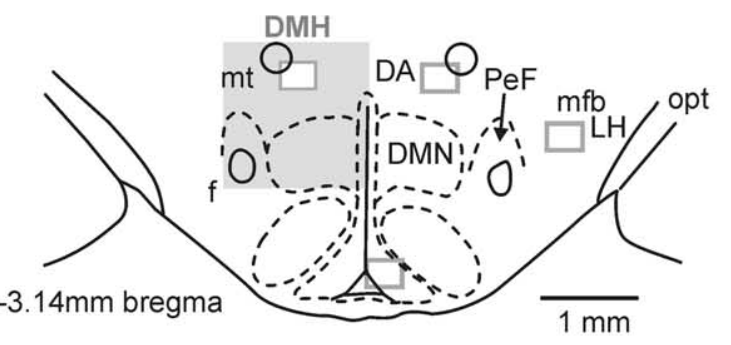

D.
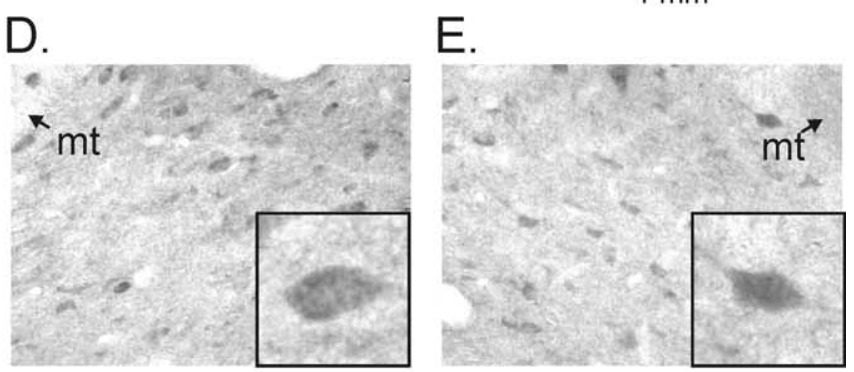

$\mathrm{F}$.

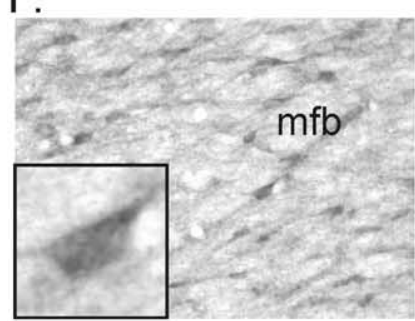

G.

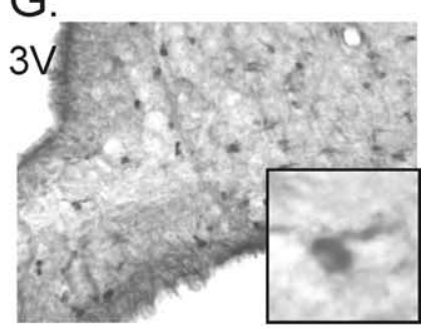

$\mathrm{H}$.

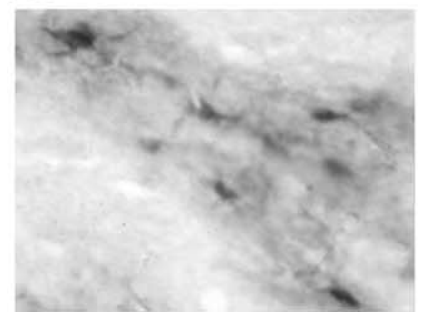

I.

Figure 7. Immunohistochemical localization of the $\mathrm{AT}_{1} \mathrm{R}$ in the $\mathrm{DMH}$ of an adult male rat. $\boldsymbol{A}_{\boldsymbol{t}}$ Western blotting of the different dilutions of the $A T_{1} R$ with different concentrations of rat brain lysate. $\boldsymbol{B}$, Western blotting for the $A T_{1} R$ in rat brain lysate after previous incubation of the $A T_{1} R$ antibody without (control) and with a $5 \times, 10 \times$, and $20 \times$ concentration of an $\mathrm{AT}_{1 \mathrm{~A}} \mathrm{R}$ and $\mathrm{AT}_{1 \mathrm{~B}} \mathrm{R}$ mixture. C, lllustration of the a rat brain section ( $-3.14 \mathrm{~mm}$ from bregma) containing the DMN, dorsal hypothalamic area (DA), LH, median eminence (ME), and PeF, adapted from a standard stereotaxic rat brain atlas. The gray-filled rectangle represents the $\mathrm{DMH}$, which is a region that is particularly sensitive to BMI-induced cardioexcitatory response (Samuels et al., 2004) and receives projections from CVOs such as the OVLT (Thompson and Swanson, 1998) and contains the DMN, dorsal hypothalamic area, and PeF. Boxes with gray lines represent regions photograph ( $\boldsymbol{D}, \boldsymbol{E}$, dorsal hypothalamic area; $\boldsymbol{F}, \mathbf{L H} ; \boldsymbol{G}$, median eminence). High-magnification photographs of $A T_{1} R$-immunopositive cells in the rat dorsal hypothalamic area $(\boldsymbol{D}, \boldsymbol{E}), \mathrm{LH}(\boldsymbol{F})$, and median eminence $(\boldsymbol{G})$. High-magnification photograph of the $\mathrm{AT}_{1} \mathrm{R}$-immunopositive cells in the DMH with a 1:500 concentration of $\mathrm{AT}_{1} \mathrm{R}$ antibody without $(\boldsymbol{I})$ and with $(J) 10 \times$

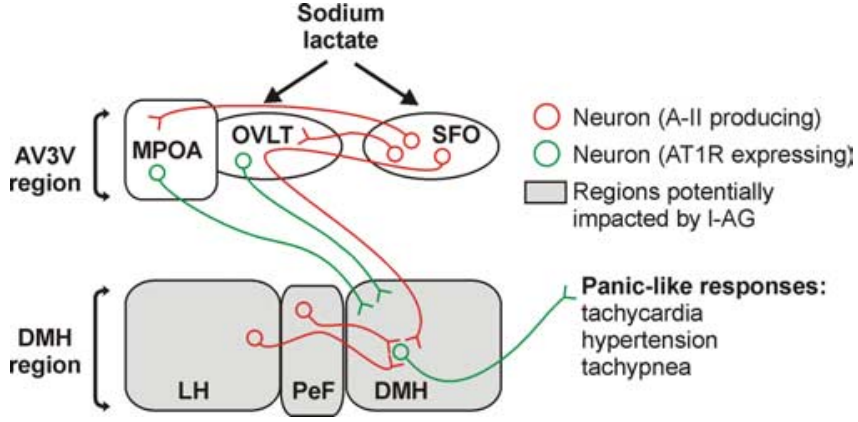

Figure 8. Hypothetical representation of the neural circuit of the A-II pathways implicated in the panic-like responses to lactate infusions in rats that have a disruption of GABA synthesis in the DMH region.

(Saavedra, 2005; Saavedra et al., 2006). The present findings further support this approach and suggest that $\mathrm{AT}_{1} \mathrm{R}$ may be a therapeutic target in panic disorder.

Both types of A-II receptors have been described previously in a number of hypothalamic nuclei (Gehlert et al., 1991; Song et al., 1992; Phillips et al., 1993; Lenkei et al., 1995, 1996, 1998; Oldfield et al., 2001; Thomas et al., 2003). Previous studies have demonstrated that radioligand binding of saralasin in the $\mathrm{DMH}$ and surrounding regions was blocked by previous incubation with a specific $\mathrm{AT}_{1} \mathrm{R}$ antagonist (i.e., losartan) but not with an A-II type 2 receptor antagonist (i.e., WL19), suggesting that saralasin injections in the DMH block panic-like responses by acting at $\mathrm{AT}_{1} \mathrm{R}$ (Gehlert et al., 1991; Song et al., 1992). The presence of $\mathrm{AT}_{1} \mathrm{R}$, but either low expression or no $\mathrm{AT}_{2} \mathrm{Rs}$, in the $\mathrm{DMH}$ is also consistent with other radioligand binding (Israel et al., 1985; Obermuller et al., 1991; Hauser et al., 1998) (for review, see Allen et al., 1998) and mRNA expression (for review, see Lenkei et al., 1997) in the hypothalamus, including the DMH (Johren et al., 1997). The DMH also contains a moderate terminal field of A-IIimmunoreactive fibers (Lind et al., 1984) (for review, see Lenkei et al., 1997). Although there appears to be abundant information regarding the presence of the $\mathrm{AT}_{1} \mathrm{R}$ in the $\mathrm{DMH}$ using radioligand binding and $\mathrm{mRNA}$, less is known about the distribution of the $\mathrm{AT}_{1} \mathrm{R}$ protein in the $\mathrm{DMH}$. Therefore, the presence of $\mathrm{AT}_{1} \mathrm{R}$ in the region of the DMH was demonstrated in this study using immunohistochemistry. Thus, these results are the first to implicate $\mathrm{A}-\mathrm{II}$ and the $\mathrm{AT}_{1} \mathrm{R}$ as putative neurotransmitter receptor in sodium lactate-induced panic-like responses, but what is the source of A-II in the DMH?

A-II-producing cells are preferentially found in the brain structures such as the hypothalamus, CVOs, and the brainstem (Saavedra and Chevillard, 1982; Saavedra et al., 1982). In a previous study, we demonstrated that the region of the AV3V was critical for the detection of lactate infusion stimulus in these panic-prone rats (Shekhar and Keim, 1997). Within the AV3V region, the SFO has cells that produce A-II as evidenced by the presence of cells that are immunoreactive for angiotensin converting enzyme (ACE) and A-II after intracerebroventricular colchicine treatment (Lind et al., 1985a,b). It may be that the SFO is one source of A-II release in the DMH. The organum vasculosum stria terminalis/median preoptic area (OVLT/MPOA) region of the AV3V is another critical relay site for the lactate stimulus.

$\leftarrow$

concentration of an $\mathrm{AT}_{1 \mathrm{~A}}$ R and $A \mathrm{~T}_{1 \mathrm{~B}} \mathrm{R}$ mixture. Scale bar: $\boldsymbol{D}, 100 \mu \mathrm{m} ; \boldsymbol{E}, \boldsymbol{F}, 50 \mu \mathrm{m}$; bottom right insets in $\boldsymbol{E}, \boldsymbol{F}, 17 \mu \mathrm{m} ; \boldsymbol{G}, \boldsymbol{H}, 42 \mu \mathrm{m} ; \boldsymbol{I}, 50 \mu \mathrm{m}$. 3V, Third ventricle; f, fornix; mfb, median forebrain bundle; mt, mammillothalamic tract; opt, optic tract. 
However, although ACE and A-II are present in the OVLT/ MPOA region, they appear to be expressed in primarily fibers and not in cells (Saavedra and Chevillard, 1982; Lind et al., 1985b), making this source of A-II questionable.

Another likely source of A-II is within the region of the hypothalamus itself. Lind et al. (1984, 1985b) used colchicine and immunohistochemistry to verify the distribution of cells that produce A-II, and, in addition to seeing A-II-positive cells in the SFO, they also detected many A-II-immunoreactive cells in the perifornical nucleus $(\mathrm{PeF})$, which is immediately lateral to the $\mathrm{DMH}$ and most likely impacted by L-AG infusions (Fig. 8). In control rats in which local GABAergic inhibitory mechanisms are unimpaired, the lactate signal arising from the AV3V region may be inadequate to induce release of sufficient A-II from PeF cells to produce a significant behavioral and physiological response. However, in L-AG-treated rats in which GABAergic inhibition is compromised, the same signal may cause release of enough A-II to act on local $\mathrm{AT}_{1} \mathrm{Rs}$ in the $\mathrm{DMH}$ and elicit panic-like effects. Alternatively, the release of A-II by relevant neurons in the PeF may be similar in control and panic-prone animals, but changes in $\mathrm{AT}_{1} \mathrm{R}$ may occur as shown in other stress conditions (Leong et al., 2002). Thus, a combination of a compromised central site capable of generating panic-like responses, such as the $\mathrm{DMH}$, and the excitatory A-II-mediated input appear to be necessary for lactate-induced panic attacks. A diagrammatic summary of the neural circuitry relevant to these phenomena and their proposed interactions appear in Figure 8.

The involvement of the CVOs in lactate-induced panic-like response may also explain why patients with panic disorder are susceptible to induction of panic attacks by systemic administration of a wide variety of agents such as doxapram, cholecystokinin, isoproterenol, and others (Price et al., 1995). Many of these agents, such as lactate, do not easily cross the blood-brain barrier. However, the CVOs, which lack a blood-brain barrier, can easily be exposed to these circulating substances and in turn stimulate the compromised DMH, thereby eliciting a response. Such a mechanism could also present a single unifying explanation for the existence of multiple, apparently unrelated agents that seem to induce panic attacks in panic disorder patients.

In addition to the $\mathrm{DMH}$, there are other $\mathrm{CNS}$ regions capable of eliciting a panic-like response when local GABAergic inhibition is impaired, including such regions as the basolateral amygdala (Sajdyk et al., 1999; Shekhar et al., 2003) and the midbrain central gray (Graeff et al., 1993; da Silva et al., 2003; Zanoveli et al., 2004). For example, in the basolateral amygdala in rats, repeated local microinjection of the $\mathrm{GABA}_{\mathrm{A}}$ receptor antagonist bicuculline or the stress-related peptide CRF appears to produce long-term sensitization to anxiogenic stimuli (Sanders et al., 1995; Rainnie et al., 2004) and the development of responsiveness to lactate infusions (Sajdyk et al., 1999; Sajdyk and Shekhar, 2000). The SFO, another CVO, has extensive connections with the amygdala (Thrasher and Keil, 1987) and may be an important site in eliciting the lactate response in these rats (Shekhar et al., 2003).

\section{Technical considerations}

Nonselective actions of the peptidic A-II receptor antagonists such as saralasin through non- $\mathrm{AT}_{1}$ and $\mathrm{AT}_{2}$ receptors have clearly been demonstrated in the rat (Ito and Sved, 2000; Potts et al., 2000). In addition, partial agonist activity is indicated (Bruner et al., 1983), although not clearly defined. These need to be considered while interpreting the saralasin data. However, injections of losartan that also replicated the anti-panic-like effects in the DMH strongly support the A-II hypothesis.

\section{Conclusion}

In summary, this report presents evidence supporting the involvement A-II pathways to the hypothalamus in the elicitation of a panic-like response after intravenous lactate infusions in rats with compromised regulation of hypothalamic panic-like response centers. We believe this to be the first proposal of a neural mechanism for sensitivity to systemic infusion of lactate in panic disorder patients, a clinical phenomenon that has been known but unexplained for nearly four decades. In addition, this study provides the first evidence for the involvement of A-II and hypothalamic $\mathrm{AT}_{1} \mathrm{R}$ in the neural circuitry involved in the panic-like response and development of panic disorders.

\section{References}

Abelson JL, Curtis GC (1996) Hypothalamic-pituitary-adrenal axis activity in panic disorder. 24-hour secretion of corticotropin and cortisol. Arch Gen Psychiatry 53:323-331.

Allen AM, Moeller I, Jenkins TA, Zhuo J, Aldred GP, Chai SY, Mendelsohn FA (1998) Angiotensin receptors in the nervous system. Brain Res Bull 47:17-28.

Armando I, Carranza A, Nishimura Y, Hoe KL, Barontini M, Terron JA, Falcon-Neri A, Ito T, Juorio AV, Saavedra JM (2001) Peripheral administration of an angiotensin $\mathrm{II} \mathrm{AT}_{1}$ receptor antagonist decreases the hypothalamic-pituitary-adrenal response to isolation stress. Endocrinology 142:3880-3889.

Baiardi G, Bregonzio C, Jezova M, Armando I, Saavedra JM (2004) Angiotensin II AT1 receptor blockade prolongs the lifespan of spontaneously hypertensive rats and reduces stress-induced release of catecholamines, glucocorticoids, and vasopressin. Ann NY Acad Sci 1018:131-136.

Bostwick JR, Le WD (1991) A tyrosine hydroxylase assay in microwells using coupled nonenzymatic decarboxylation of dopa. Anal Biochem 192:125-130.

Bregonzio C, Armando I, Ando H, Jezova M, Baiardi G, Saavedra JM (2003) Anti-inflammatory effects of angiotensin II AT1 receptor antagonism prevent stress-induced gastric injury. Am J Physiol Gastrointest Liver Physiol 285:G414-G423.

Bruner CA, Weaver JM, Fink GD (1983) Will chronic intracerebroventricular saralasin infusion produce selective blockade of brain angiotensin II receptors in the rat? J Pharmacol Exp Ther 226:13-18.

Charney DS, Heninger GR, Breier A (1984) Noradrenergic function in panic anxiety. Effects of yohimbine in healthy subjects and patients with agoraphobia and panic disorder. Arch Gen Psychiatry 41:751-763.

Charney DS, Heninger GR, Jatlow PI (1985) Increased anxiogenic effects of caffeine in panic disorders. Arch Gen Psychiatry 42:233-243.

Charney DS, Woods SW, Goodman WK, Heninger GR (1987) Neurobiological mechanisms of panic anxiety: biochemical and behavioral correlates of yohimbine-induced panic attacks. Am J Psychiatry 144:1030-1036.

Chen P, Smith MS (2003) Suckling-induced activation of neuronal input to the dorsomedial nucleus of the hypothalamus: possible candidates for mediating the activation of DMH neuropeptide Y neurons during lactation. Brain Res 984:11-20.

Chou TC, Scammell TE, Gooley JJ, Gaus SE, Saper CB, Lu J (2003) Critical role of dorsomedial hypothalamic nucleus in a wide range of behavioral circadian rhythms. J Neurosci 23:10691-10702.

Cowley DS, Arana GW (1990) The diagnostic utility of lactate sensitivity in panic disorder. Arch Gen Psychiatry 47:277-284.

Cowley DS, Dager SR, Dunner DL (1987) Lactate infusions in major depression without panic attacks. J Psychiatr Res 21:243-248.

da Silva LG, de Menezes RC, Souza dos Santos RA, Campagnole-Santos MJ, Peliky Fontes MA (2003) Role of periaqueductal gray on the cardiovascular response evoked by disinhibition of the dorsomedial hypothalamus. Brain Res 984:206-214.

De Matteo R, Head GA, Mayorov DN (2006) Angiotensin II in dorsomedial hypothalamus modulates cardiovascular arousal caused by stress but not feeding in rabbits. Am J Physiol Regul Integr Comp Physiol 290:R257-R264. DiMicco JA, Stotz-Potter EH, Monroe AJ, Morin SM (1996) Role of the 
dorsomedial hypothalamus in the cardiovascular response to stress. Clin Exp Pharmacol Physiol 23:171-176.

DiMicco JA, Samuels BC, Zaretskaia MV, Zaretsky DV (2002) The dorsomedial hypothalamus and the response to stress: part renaissance, part revolution. Pharmacol Biochem Behav 71:469-480.

File SE (1980) The use of social interaction as a method for detecting anxiolytic activity of chlordiazepoxide-like drugs. J Neurosci Methods 2:219-238.

Gaffney FA, Fenton BJ, Lane LD, Lake CR (1988) Hemodynamic, ventilatory, and biochemical responses of panic patients and normal controls with sodium lactate infusion and spontaneous panic attacks. Arch Gen Psychiatry 45:53-60.

Gehlert DR, Gackenheimer SL, Schober DA (1991) Autoradiographic localization of subtypes of angiotensin II antagonist binding in the rat brain. Neuroscience 44:501-514.

Giles ME, Fernley RT, Nakamura Y, Moeller I, Aldred GP, Ferraro T, Penschow JD, McKinley MJ, Oldfield BJ (1999) Characterization of a specific antibody to the rat angiotensin II AT1 receptor. J Histochem Cytochem 47:507-516.

Gorman JM, Liebowitz MR, Fyer AJ, Dillon D, Davies SO, Stein J, Klein DF (1985) Lactate infusions in obsessive-compulsive disorder. Am J Psychiatry 142:864-866.

Gorman JM, Papp LA, Coplan JD, Martinez JM, Lennon S, Goetz RR, Ross D, Klein DF (1994) Anxiogenic effects of CO2 and hyperventilation in patients with panic disorder. Am J Psychiatry 151:547-553.

Gorman JM, Kent JM, Sullivan GM, Coplan JD (2000) Neuroanatomical hypothesis of panic disorder, revised. Am J Psychiatry 157:493-505.

Graeff FG, Silveira MC, Nogueira RL, Audi EA, Oliveira RM (1993) Role of the amygdala and periaqueductal gray in anxiety and panic. Behav Brain Res 58:123-131.

Hauser W, Johren O, Saavedra JM (1998) Characterization and distribution of angiotensin II receptor subtypes in the mouse brain. Eur J Pharmacol 348:101-114.

Hoffmann A, Cool DR (2003) Angiotensin II receptor types 1A, 1B, and 2 in murine neuroblastoma Neuro-2a cells. J Recept Signal Transduct Res 23:111-121.

Huang J, Hara Y, Anrather J, Speth RC, Iadecola C, Pickel VM (2003) Angiotensin II subtype 1A (AT1A) receptors in the rat sensory vagal complex: subcellular localization and association with endogenous angiotensin. Neuroscience 122:21-36.

Imanishi K, Nonoguchi H, Nakayama Y, Machida K, Ikebe M, Tomita K (2003) Type 1A angiotensin II receptor is regulated differently in proximal and distal nephron segments. Hypertens Res 26:405-411.

Israel A, Plunkett LM, Saavedra JM (1985) Quantitative autoradiographic characterization of receptors for angiotensin II and other neuropeptides in individual brain nuclei and peripheral tissues from single rats. Cell Mol Neurobiol 5:211-222.

Ito S, Sved AF (2000) Pharmacological profile of depressor response elicited by sarthran in rat ventrolateral medulla. Am J Physiol Heart Circ Physiol 279:H2961-H2966.

Javanmard M, Shlik J, Kennedy SH, Vaccarino FJ, Houle S, Bradwejn J (1999) Neuroanatomic correlates of CCK-4-induced panic attacks in healthy humans: a comparison of two time points. Biol Psychiatry 45:872-882.

Jensen CF, Peskind ER, Keller TW, McFall ME, Raskind MA (1998) Comparison of sodium lactate-induced panic symptoms between panic disorder and posttraumatic stress disorder. Depress Anxiety 7:122-125.

Johren O, Imboden H, Hauser W, Maye I, Sanvitto GL, Saavedra JM (1997) Localization of angiotensin-converting enzyme, angiotensin II, angiotensin II receptor subtypes, and vasopressin in the mouse hypothalamus. Brain Res 757:218-227.

Lenkei Z, Corvol P, Llorens-Cortes C (1995) The angiotensin receptor subtype AT1A predominates in rat forebrain areas involved in blood pressure, body fluid homeostasis and neuroendocrine control. Brain Res Mol Brain Res 30:53-60.

Lenkei Z, Palkovits M, Corvol P, Llorens-Cortes C (1996) Distribution of angiotensin II type-2 receptor (AT2) mRNA expression in the adult rat brain. J Comp Neurol 373:322-339.

Lenkei Z, Palkovits M, Corvol P, Llorens-Cortes C (1997) Expression of angiotensin type-1 (AT1) and type-2 (AT2) receptor mRNAs in the adult rat brain: a functional neuroanatomical review. Front Neuroendocrinol 18:383-439.
Lenkei Z, Palkovits M, Corvol P, Llorens-Cortes C (1998) Distribution of angiotensin type-1 receptor messenger RNA expression in the adult rat brain. Neuroscience 82:827-841.

Leong DS, Terron JA, Falcon-Neri A, Armando I, Ito T, Johren O, Tonelli LH, Hoe KL, Saavedra JM (2002) Restraint stress modulates brain, pituitary and adrenal expression of angiotensin $\mathrm{II}_{\mathrm{AT}}, \mathrm{AT}_{1 \mathrm{~B}}$, and $\mathrm{AT}_{2}$ receptors. Neuroendocrinology 75:227-240.

Liebowitz MR, Fyer AJ, Gorman JM, Dillon D, Appleby IL, Levy G, Anderson S, Levitt M, Palij M, Davies SO (1984) Lactate provocation of panic attacks. I. Clinical and behavioral findings. Arch Gen Psychiatry 41:764-770.

Liebowitz MR, Fyer AJ, Gorman JM, Dillon D, Davies S, Stein JM, Cohen BS, Klein DF (1985) Specificity of lactate infusions in social phobia versus panic disorders. Am J Psychiatry 142:947-950.

Lind RW, Swanson LW, Ganten D (1984) Angiotensin II immunoreactivity in the neural afferents and efferents of the subfornical organ of the rat. Brain Res 321:209-215.

Lind RW, Swanson LW, Bruhn TO, Ganten D (1985a) The distribution of angiotensin II-immunoreactive cells and fibers in the paraventriculohypophysial system of the rat. Brain Res 338:81-89.

Lind RW, Swanson LW, Ganten D (1985b) Organization of angiotensin II immunoreactive cells and fibers in the rat central nervous system. An immunohistochemical study. Neuroendocrinology 40:2-24.

Lipp A, Tank J, Trottenberg T, Kupsch A, Arnold G, Jordan J (2005) Sympathetic activation due to deep brain stimulation in the region of the STN. Neurology 65:774-775.

Lowry CA, Plant A, Shanks N, Ingram CD, Lightman SL (2003) Anatomical and functional evidence for a stress-responsive, monoamineaccumulating area in the dorsomedial hypothalamus of adult rat brain. Horm Behav 43:254-262.

McGrath PJ, Stewart JW, Liebowitz MR, Markowitz JM, Quitkin FM, Klein DF, Gorman JM (1988) Lactate provocation of panic attacks in depressed outpatients. Psychiatry Res 25:41-47.

Obermuller N, Unger T, Culman J, Gohlke P, De Gasparo M, Bottari SP (1991) Distribution of angiotensin II receptor subtypes in rat brain nuclei. Neurosci Lett 132:11-15.

Oldfield BJ, Davern PJ, Giles ME, Allen AM, Badoer E, McKinley MJ (2001) Efferent neural projections of angiotensin receptor (AT1) expressing neurones in the hypothalamic paraventricular nucleus of the rat. J Neuroendocrinol 13:139-146.

Paxinos G, Watson C (1986) The rat brain in stereotaxic coordinates. New York: Academic.

Phillips MI, Shen L, Richards EM, Raizada MK (1993) Immunohistochemical mapping of angiotensin AT1 receptors in the brain. Regul Pept 44:95-107.

Pitts Jr FN, McClure Jr JN (1967) Lactate metabolism in anxiety neurosis. N Engl J Med 277:1329-1336.

Potts PD, Allen AM, Horiuchi J, Dampney RA (2000) Does angiotensin II have a significant tonic action on cardiovascular neurons in the rostral and caudal VLM? Am J Physiol Regul Integr Comp Physiol 279:R1392-R1402.

Price L, Goddard A, Barr L, Goodman W (1995) Pharmacological challenges in anxiety disorders. In: Psychopharmacology: the fourth generation of progression (Bloom F, Kupfers D, eds), pp 1311-1323. New York: Raven.

Rainey Jr JM, Aleem A, Ortiz A, Yeragani V, Pohl R, Berchou R (1987) A laboratory procedure for the induction of flashbacks. Am J Psychiatry 144:1317-1319.

Rainnie DG, Bergeron R, Sajdyk TJ, Patil M, Gehlert DR, Shekhar A (2004) Corticotrophin releasing factor-induced synaptic plasticity in the amygdala translates stress into emotional disorders. J Neurosci 24:3471-3479.

Reiman EM, Raichle ME, Butler FK, Herscovitch P, Robins E (1984) A focal brain abnormality in panic disorder, a severe form of anxiety. Nature 310:683-685.

Saavedra JM (2005) Brain angiotensin II: new developments, unanswered questions and therapeutic opportunities. Cell Mol Neurobiol 25:485-512.

Saavedra JM, Chevillard C (1982) Angiotensin-converting enzyme is present in the subfornical organ and other circumventricular organs of the rat. Neurosci Lett 29:123-127.

Saavedra JM, Fernandez-Pardal J, Chevillard C (1982) Angiotensinconverting enzyme in discrete areas of the rat forebrain and pituitary gland. Brain Res 245:317-325. 
Saavedra JM, Ando H, Armando I, Baiardi G, Bregonzio C, Jezova M, Zhou J (2004) Brain angiotensin II, an important stress hormone: regulatory sites and therapeutic opportunities. Ann NY Acad Sci 1018:76-84.

Saavedra JM, Armando I, Bregonzio C, Juorio A, Macova M, Pavel J, SanchezLemus E (2006) A centrally acting, anxiolytic angiotensin II AT 1 receptor antagonist prevents the isolation stress-induced decrease in cortical $\mathrm{CRF}_{1}$ receptor and benzodiazepine binding. Neuropsychopharmacology 31:1123-1134.

Sajdyk TJ, Shekhar A (2000) Sodium lactate elicits anxiety in rats after repeated GABA receptor blockade in the basolateral amygdala. Eur J Pharmacol 394:265-273.

Sajdyk TJ, Schober DA, Gehlert DR, Shekhar A (1999) Role of corticotropin-releasing factor and urocortin within the basolateral amygdala of rats in anxiety and panic responses. Behav Brain Res 100:207-215.

Samuels BC, Zaretsky DV, DiMicco JA (2002) Tachycardia evoked by disinhibition of the dorsomedial hypothalamus in rats is mediated through medullary raphe. J Physiol (Lond) 538:941-946.

Samuels BC, Zaretsky DV, DiMicco JA (2004) Dorsomedial hypothalamic sites where disinhibition evokes tachycardia correlate with location of raphe-projecting neurons. Am J Physiol Regul Integr Comp Physiol 287:R472-R478.

Sanders SK, Morzorati SL, Shekhar A (1995) Priming of experimental anxiety by repeated subthreshold GABA blockade in the rat amygdala. Brain Res 699:250-259.

Sano K, Mayanagi Y, Sekino H, Ogashiwa M, Ishijima B (1970) Results of timulation and destruction of the posterior hypothalamus in man. J Neurosurg 33:689-707.

Schreiber W, Lauer CJ, Krumrey K, Holsboer F, Krieg JC (1996) Dysregulation of the hypothalamic-pituitary-adrenocortical system in panic disorder. Neuropsychopharmacology 15:7-15.

Shekhar A (1993) GABA receptors in the region of the dorsomedial hypothalamus of rats regulate anxiety in the elevated plus-maze test. I. Behavioral measures. Brain Res 627:9-16.

Shekhar A, DiMicco JA (1987) Defense reaction elicited by injection of GABA antagonists and synthesis inhibitors into the posterior hypothalamus in rats. Neuropharmacology 26:407-417.

Shekhar A, Keim SR (1997) The circumventricular organs form a potential neural pathway for lactate sensitivity: implications for panic disorder. J Neurosci 17:9726-9735.
Shekhar A, Keim SR (2000) LY354740, a potent group II metabotropic glutamate receptor agonist prevents lactate-induced panic-like response in panic-prone rats. Neuropharmacology 39:1139-1146.

Shekhar A, Keim SR, Simon JR, McBride WJ (1996) Dorsomedial hypothalamic GABA dysfunction produces physiological arousal following sodium lactate infusions. Pharmacol Biochem Behav 55:249-256.

Shekhar A, Sajdyk TJ, Goddard AW (2002) Neurobiology of panic disorder. Trends Econom Neurobiol 4:36-41.

Shekhar A, Sajdyk TJ, Gehlert DR, Rainnie DG (2003) The amygdala, panic disorder, and cardiovascular responses. Ann NY Acad Sci 985:308-325.

Song K, Allen AM, Paxinos G, Mendelsohn FA (1992) Mapping of angiotensin II receptor subtype heterogeneity in rat brain. J Comp Neurol 316:467-484.

Strohle A, Romeo E, di Michele F, Pasini A, Hermann B, Gajewsky G, Holsboer F, Rupprecht R (2003) Induced panic attacks shift gammaaminobutyric acid type A receptor modulatory neuroactive steroid composition in patients with panic disorder: preliminary results. Arch Gen Psychiatry 60:161-168.

Ter Horst GJ, Luiten PG (1986) The projections of the dorsomedial hypothalamic nucleus in the rat. Brain Res Bull 16:231-248.

Thomas MA, Hauptfleisch S, Fleissner G, Lemmer B (2003) Localization of angiotensin II (AT1)-receptor-immunoreactive fibres in the hypothalamus of rats: angiotensin II-sensitive tanycytes in the ependyma of the third ventricle? Brain Res 967:281-284.

Thompson RH, Swanson LW (1998) Organization of inputs to the dorsomedial nucleus of the hypothalamus: a reexamination with Fluorogold and PHAL in the rat. Brain Res Brain Res Rev 27:89-118.

Thrasher TN, Keil LC (1987) Regulation of drinking and vasopressin secretion: role of organum vasculosum laminae terminalis. Am J Physiol 253:R108-R120.

Van de Kar LD, Blair ML (1999) Forebrain pathways mediating stressinduced hormone secretion. Front Neuroendocrinol 20:1-48.

Wang G, Anrather J, Huang J, Speth RC, Pickel VM, Iadecola C (2004) NADPH oxidase contributes to angiotensin II signaling in the nucleus tractus solitarius. J Neurosci 24:5516-5524.

Zanoveli JM, Netto CF, Guimaraes FS, Zangrossi Jr H (2004) Systemic and intra-dorsal periaqueductal gray injections of cholecystokinin sulfated octapeptide (CCK-8s) induce a panic-like response in rats submitted to the elevated T-maze. Peptides 25:1935-1941. 